\title{
THE ROLE OF PARENTS AND TEACHERS IN SUPERVISING PRIMARY SCHOOL STUDENT'S ATTITUDE DUE TO INFLUENCE FROM TECHNOLOGY BASED ON INDUSTRIAL REVOLUTION 4.0
}

\author{
Bayu Purbha Sakti ${ }^{\star}$ \\ Universitas Widya Dharma Klaten \\ bayups@unwidha.ac.id
}

\begin{abstract}
Technology in the Industrial Revolution 4.0 currently has a negative impact on elementary school students. These students easily access various kinds of content ranging from educating to negative ones. Attention, supervision, and parental consultation to the teacher is very decisive towards the development of attitudes and behavior of elementary school students. The development of students who are not directed will certainly affect the conditions that occur in the school environment and in the surrounding environment. Students are easily influenced by technological sophistication in the development of the current era. Students are also easily addicted to playing digital technology from the Industrial Revolution 4.0. Parents and teachers need to provide moral values and positive values so that students do not easily fall into negative things and can screen the spectacle they should see. The role of parents and teachers has the same supervision in terms of educating elementary school students but the difference is obtained in its place. Primary students are educated and supervised by parents at home, while teachers supervise elementary school students at school. Supervision of teachers and parents is very instrumental in shaping the attitudes and personalities of children to be better and disciplined.
\end{abstract}

Keywords: Industrial Revolution 4.0, Parental Supervision, Teacher Oversight, Digital Technology

\begin{abstract}
ABSTRAK
Teknologi dalam Revolusi Industri 4.0 saat ini memiliki dampak negatif bagi siswa sekolah dasar. Siswa tersebut mudah mengakses berbagai macam konten mulai dari yang mendidik sampai yang bersifat negatif. Perhatian, pengawasan, dan konsultasi orang tua ke guru sangatlah menentukan terhadap perkembangan sikap dan perilaku siswa sekolah dasar. Perkembangan siswa yang tidak terarah tentunya akan mempengaruhi kondisi yang terjadi di lingkungan sekolah dan di lingkungan sekitar. Siswa mudah terpengaruh oleh kecanggihan teknologi pada perkembangan zaman saat ini. Siswa juga mudah kecanduan dalam memainkan teknologi digital dari Revolusi Industri 4.0. Orang tua dan guru perlu memberikan penanaman nilai-nilai moral dan nilai-nilai positif agar siswa tidak mudah terjerumus ke dalam hal-hal yang negatif dan dapat menyaring tontonan yang sebaiknya ia lihat. Peran orang tua dan guru memiliki kesamaan pengawasan dalam hal mendidik siswa sekolah dasar tetapi perbedaannya didapatkan pada tempatnya. Siswa sekolah dasar di didik dan diawasi oleh orang tua di rumah, sedangkan guru yang mengawasi siswa sekolah dasar di sekolah. Pengawasan guru dan orang tua sangat berperan untuk membentuk sikap dan pribadi anak menjadi lebih baik dan disiplin.
\end{abstract}

Kata kunci: Revolusi Industri 4.0, Pengawasan Orang Tua, Pengawasan Guru, Teknologi Digital

\section{PENDAHULUAN}

Perkembangan ketrampilan, pengetahuan, dan sikap siswa di sekolah dasar harus diawasi oleh guru yang berada di sekolah walaupun begitu di lingkungan sekitar orang tua juga harus mengawasi perkembangan siswa. Namun ada masalah jika daya tampung sekolah dasar tidak sesuai dengan standard yang diterapkan seperti kasus Pendaftaran Peserta Didik Baru (PPDB) sekolah dasar di Batam. Daya tampung sekolah dasar yang ada tidak sanggup menampung jumlah anak yang ada (Yul, 2019). Daya tampung yang banyak akan mempengaruhi sikap dan perkembangan siswa sekolah dasar.

Guru dan orang tua memiliki hubungan timbal balik untuk menjaga dan mengawasi perkembangan sikap siswa di sekolah maupun di lingkungan sekitar. Dari berbagai faktor 
yang ada salah satu yang mengakibatan perubahan sikap siswa yaitu dengan adanya perkembangan teknologi. Pihak United Nations Children's Fund (UNICEF) menyebutkan bahwa penggunaan internet di Indonesia dari kalangan anak-anak dan remaja diprediksi mencapai 30 juta (Purwadi, 2019).

Berkembangnya teknologi digital saat ini, memudahkan siswa dalam mengakses berbagai macam konten mulai dari yang mendidik sampai yang bersifat negatif. Dari berbagai konten yang disediakan, ada siswa yang mengakses hal-hal yang mendidik tetapi ada pula siswa yang mengakses hal-hal yang negative. Dengan rasa keingin tahuan siswa yang tinggi sehingga mereka mencoba untuk mengikuti hal-hal yang tidak baik. Apalagi konten digital banyak yang bersifat negatif, seperti konten pornografi, kekerasan, informasi hoax, dan lainnya (Suherlan, 2018).

Jangan lagi mudah diprovokasi oleh berita-berita hoax akibat perkembangan Revolusi Industri 4.0 ini (Maharani, 2019). Siswa sekolah dasar diharapkan tidak mudah terpengaruh oleh berita bohong (hoax). Hal tersebut akan mempengaruhi sikap siswa sekolah dasar dalam menanggapi berita-berita yang beredar di berbagai media.

Perkembangan siswa sekolah dasar yang tidak terarah tentunya akan mempengaruhi kondisi yang terjadi di lingkungan sekolah dan di lingkungan sekitar. Siswa mudah terpengaruh oleh kecanggihan teknologi pada perkembangan zaman saat ini. Revolusi industri 4.0 memiliki dampak negatif yaitu jutaan tenaga kerja bisa menganggur dengan seketika (Gih, 2019). Siswa sekolah dasar juga bisa menganggur belajar karena kecanduan dengan teknologi digital yang telah dihasilkan dari revolusi ini.

Tayangan televisi yang tidak pantas ditonton untuk anak di bawah umur sekarang sudah banyak tayang (Natarida, 2016). Apalagi bagi siswa yang tidak diperhatikan orang tuanya mereka mencoba mencari perhatian dari orang lain atau media lain dengan hal-hal yang tidak baik. Oleh karena itu, pengawasan dari orang tua dan guru sangatlah diperlukan.

Perhatian, pengawasan, dan konsultasi orang tua ke guru yang berkurang akan mengakibatkan siswa tidak terarah dalam mengembangkan perilaku di lingkungan sekolah dan di lingkungan sekitar. Guru dituntut berperan aktif dalam mengembangkan pengetahuan dan memberikan contoh sikap yang baik sesuai dengan norma yang berlaku. Orang tua dituntut mampu mengawasi perkembangan sikap anak terutama di lingkungan rumah. Dalam hal ini guru dan orang tua mempunyai tanggung jawab yang sama agar tidak terjadi kesenjangan perilaku anak disekolah dan dirumah. Lingkungan sekolah yang tidak menguntungkan memiliki pengaruh terhadap sikap yang ditunjukkan siswa sekolah dasar. Kurikulum yang tidak jelas, guru yang kurang memahawi kejiwaan anak dan sarana sekolah yang kurang memadai sering menyebabkan munculnya sikap menyimpang pada siswa sekolah dasar.

Berdasarkan beberapa masalah yang telah dijelaskan maka ada perumusan masalah yang harus dituliskan. Rumusan masalah yang dapat dituliskan antara lain yaitu peran orang tua dalam mengawasi sikap siswa sekolah dan peran guru dalam mengatasi sikap yang menyimpang dari siswa.

\section{PEMBAHASAN}

\section{A. Peran Orang Tua Dalam Mengawasi Sikap Siswa Sekolah Dasar 1. Orang tua yang mendidik}

Keluarga dan masyarakat memiliki peran demi keamanan anak usia sekolah dasar (Sakti, 2016b). Saat ini masyarakat semakin menyadari pentingnya memberikan pendidikan yang terbaik kepada anak-anak mereka sejak dini. Untuk itu orang tua memegang peranan yang sangat penting dalam membimbing dan mendampingi anak dalam kehidupan keseharian anak. Sudah merupakan 
kewajiban para orang tua untuk menciptakan lingkungan yang kondusif sehingga dapat memancing keluar potensi anak, kecerdasan dan rasa percaya diri. Dan tidak lupa memahami tahap perkembangan anak serta kebutuhan pengembangan potensi kecerdasan dari setiap tahap.

Orang tua memiliki peran dalam hal pendidikan anak sudah seharusnya berada pada urutan pertama, para orang tualah yang paling mengerti benar akan sifat-sifat baik dan buruk anak-anaknya, apa saja yang mereka sukai dan apa saja yang mereka tidak sukai. Para orang tua adalah yang pertama kali tahu bagaimana perubahan dan perkembangan karakter dan kepribadian anak-anaknya, hal-hal apa saja yang membuat anaknya malu dan hal-hal apa saja yang membuat anaknya takut. Para orang tualah yang nantinya akan menjadikan anak-anak mereka seorang yang memiliki kepribadian baik ataukah buruk.

Ada banyak cara untuk memberikan pendidikan kepada anak baik formal maupun non formal. Adapun pendidikan formal tidak sebatas dengan memberikan pengetahuan dan keahlian kepada anak-anak mereka di sekolah. Selain itu pendidikan non formal menanamkan tata nilai yang serba luhur atau ahlak mulia, norma-norma, cita-cita, tingkah laku dan aspirasi dengan bimbingan orang tua di rumah.

Sekolah sebagai salah satu sarana pendidikan formal memerlukan banyak hal yang mendukung yaitu antara lain kepentingan dan kualitas yang baik dari kepala sekolah dan guru, peran aktif dinas pendidikan atau pengawas sekolah, peran aktif orangtua dan peran aktif masyarakat sekitar sekolah. Akan tetapi orang tua juga tidak dapat menyerahkan sepenuhnya pendidikan anak kepada sekolah. Pendidikan anak dimulai dari pendidikan orang tua di rumah dan orang tua yang mempunyai tanggung jawab utama terhadap masa depan anak-anak mereka. Sekolah hanya merupakan lembaga yang membantu proses tersebut. Sehingga peran aktif dari orang tua sangat diperlukan bagi keberhasilan anak-anak di sekolah.

Ada beberapa cara dalam meningkatkan peran orang tua terhadap pendidikan anak-anak mereka, antara lain :

a. Pertama, dengan mengontrol waktu belajar dan cara belajar anak. Anak-anak diajarkan untuk belajar secara rutin, tidak hanya belajar saat mendapat pekerjaan rumah dari sekolah atau akan menghadapi ulangan. Setiap hari anak-anak diajarkan untuk mengulang pelajaran yang diberikan oleh guru pada hari itu. Dan diberikan pengertian kapan anak-anak mempunyai waktu untuk bermain.

b. Kedua, memantau perkembangan kemampuan akademik anak. Orang tua diminta untuk memeriksa nilai-nilai ulangan dan tugas anak mereka.

c. Ketiga, memantau perkembangan kepribadian yang mencakup sikap, moral dan tingkah laku anak-anak. Hal ini dapat dilakukan orang tua dengan berkomunikasi dengan wali kelas untuk mengetahui perkembangan anak di sekolah.

d. Keempat, memantau efektifitas jam belajar di sekolah. Orang tua dapat menanyakan aktifitas yang dilakukan anak mereka selama berada di sekolah. Dan tugas-tugas apa saja yang diberikan oleh guru mereka.

Orang tua juga harus selalu aktif berkomunikasi dengan guru untuk mendapatkan informasi pendidikan anaknya. Kompetensi sosial adalah kemampuan guru untuk berkomunikasi dan berinteraksi secara efektif dan efisien dengan peserta didik, sesama guru, orang tua/wali peserta didik, dan masyarakat sekitar (Sakti, 2016a). Orang tua harus lebih memperhatikan anak-anak mereka, melihat potensi dan bakat yang ada di diri anak-anak mereka, memberikan sarana dan prasarana 
untuk mendukung proses pembelajaran mereka di sekolah. Para orang tua diharapkan dapat melakukan semua itu dengan niat yang tulus untuk menciptakan generasi yang mempunyai moral yang luhur dan wawasan yang tinggi serta semangat pantang menyerah.

\section{Orang tua yang mengarahkan}

Harapan terbesar orang tua adalah ingin mengarahkan anak yang soleh, sopan, pandai bergaul, pintar dan sukses, tetapi harapan besar ini jangan sampai menjadi tinggal harapan saja. Kedudukan dan fungsi suatu keluarga dalam kehidupan manusia sangatlah penting dan fundamental, keluarga pada hakekatnya merupakan wadah pembentukan masing-masing anggotanya, terutama anak-anak yang masih berada dalam bimbingan tanggung jawab orang tuanya.

Materi karakter meliputi kualitas emosional, intelektual, dan moral dari seseorang atau sekelompok seperti demonstrasi dari kualitas-kualitasnya dalam perilaku prososial (Sakti, 2017a). Orang tua ingin mengarahkan perkembangan anak pada umumnya yang meliputi keadaan fisik, emosional sosial dan intelektual. Ada periode-periode kritis dalam perkembangan jiwa yang berarti bahwa bila periodeperiode ini tidak dapat dilalui dengan baik, maka akan timbul gejala-gejala yang menunjukan misalnya keterlambatan, ketegangan, kesulitan penyesuaian diri dan kepribadian yang terganggu. Tugas manusia sebagai makhluk sosial untuk mengadakan hubungan antar manusia yang memuaskan baik untuk diri sendiri maupun untuk orang di lingkungannya akan gagal sama sekali.

Pada banyak kasus, orang tua sering memaksakan kehendak mereka terhadap anak-anak mereka tanpa mengindahkan pikiran dan suara hati anak. Orang tua merasa paling tahu apa yang terbaik untuk anak-anak mereka. Hal ini sering dilakukan oleh orang tua yang berusaha mewujudkan impian mereka, yang tidak dapat mereka raih saat mereka masih muda, melalui anak mereka. Kejadian seperti ini tidak seharusnya terjadi jika orang tua menyadari potensi dan bakat yang dimiliki oleh anak mereka. Serta memberikan dukungan moril dan sarana untuk membantu anak mereka mengembangkan potensi dan bakat yang ada.

Kesalahan-kesalahan yang dilakukan oleh orang tua dan harus dihindari dalam mendidik anak mereka, antara lain menumbuhkan rasa takut dan minder pada anak, mendidik anak menjadi sombong terhadap orang lain, membiasakan anak hidup berfoya-foya, selalu memenuhi permintaan anak, terutama ketika anak sedang menangis, terlalu keras dan kaku dalam menghadapi anak, terlalu pelit terhadap anak (melebihi batas kewajaran), tidak mengasihi dan menyayangi mereka sehingga mereka mencari kasih sayang di luar rumah, orang tua hanya memperhatikan kebutuhan jasmaninya saja, orang tua terlalu berprasangka baik kepada anak-anak mereka.

Selain semua hal di atas ada beberapa hal lain yang perlu diperhatikan yaitu membantu anak mengenali dirinya (kekuatan dan kelemahannya), membantu anak mengembangkan potensi sesuai bakat dan minatnya, membantu meletakkan pondasi yang kokoh untuk keberhasilan hidup anak dan membantu anak merancang hidupnya.

Pada umumnya orangtua akan lebih mengarahkan perkembangan dan kebutuhan rohani anak ketika ia masih kecil saja. Pada saat ia mulai meginjak remaja, biasanya perhatian orangtua semakin memudar. Hal itu terjadi mungkin karena mereka menganggap anak sudah dapat mandiri dan sudah tidak terlalu banyak lagi membutuhkan perhatian atau bantuan orangtua.

Jika orangtua selalu memberikan perhatian secara aktif. Selalu berusaha melibatkan diri dalam hidup anak, misalnya mendengarkan apa yang ingin ia 
bicarakan, memotivasi kegiatan sekolahnya, dan membantu anak ketika ia sedang mendapatkan masalah dalam hidupnya. Maka, ketika ia mengetahui hal ini di masa depan nanti, ia akan siap pula memberikan yang terbaik kepada orangtuanya. la akan siap mendampingi dan memerhatikan orangtua seperti halnya orangtua telah melakukan semua itu kepadanya. Apabila orangtua mampu menunjukkan kepada anak betapa orangtua sangat mencintai dan menyayanginya, dengan selalu mengekspresikan perhatian secara mendetail terhadap kehidupan anak sejak ia masih kecil, maka hal ini akan menciptakan suatu kebiasaan intim seumur hidup yang memberikan manfaat bagi orangtua.

Anak akan mampu mengingat segala kejadian yang pernah ia alami dalam hidupnya. Termasuk perlakuan orangtua kepadanya. Oleh karena itu, walaupun dalam hal yang kita anggap sepele, tetapi penting bagi orangtua menciptakan tindakan yang mencerminkan rasa cinta dan kasih sayang yang tulus itu kepada anak. Misalnya, menghadiri kegiatan ektrakurikuler anak (karate, kursus musik), mendampingi anak melakukan hobinya (berenang, membantu memilihkan buku bacaan), dan bahkan merawat anak ketika ia sedang sakit. Perlakuan orangtua seperti itu besar kemungkinan akan terbawa oleh anak sampai ia dewasa atau tua nanti. Ikatan batin, kebiasaan yang penuh dengan kehangatan, dan persahabatan yang 'melebihi segalanya' ini akan dibawanya kembali oleh anak kepada orangtua. Segala tindakan dan ucapan baik orangtua yang dulu pernah mereka tanam, cepat atau lambat mereka akan merasakan hasilnya. Di masa tua nanti, orangtua maupun anak akan hidup dalam jalinan keluarga yang penuh dengan sikap saling memberi cinta.

\section{B. Peran Guru dalam Mengatasi Sikap Siswa Sekolah Dasar}

Peran guru sebagai agen pembelajaran harus difungsikan. Guru mengembangkan peserta didik untuk mengaktualisasikan berbagai potensi yang dimilikinya (Yudhoyono, 2008). Peran guru sangatlah dibutuhkan untuk mengatasi sikap menyimpang yang ditunjukkan siswa sekolah dasar. Guru memiliki kualitas pribadi untuk mengembangkan hubungan kemanusiaan yang autentik dengan siswa, orang tua, rekan sejawat,serta untuk mengembangkan kelas yang berkeadilan sosial dan demokratis bagi anak-anak dan kaum muda (Abidin, 2017)

Guru yang memiliki motivasi akan mempermudah dalam mengatasi sikap menyimpang siswa sekolah dasar. Motivasi dapat diartikan sebagai daya penggerak yang ada di dalam diri seseorang untuk melakukan aktivitas-aktivitas tertentu demi tercapainya suatu tujuan. Motivasi diawali dengan terjadinya perubahan energi, ditandai dengan adanya feeling, dan dirangsang karena adanya tujuan. Motivasi dapat dikatakan sebagai keseluruhan daya penggerak di dalam diri siswa yang menimbulkan, menjamin kelangsungan dan memberikan arah kegiatan belajar, sehingga diharapkan tujuan dapat tercapai. Motivasi sangat diperlukan dalam kegiatan belajar karena seseorang yang tidak mempunyai motivasi dalam belajar maka dia tidak akan mungkin melakukan aktivitas belajar.

Motivasi ada dua, yaitu motivasi intrinsik dan motivasi ektrinsik. Motivasi Intrinsik adalah jenis motivasi yang timbul dari dalam diri individu sendiri tanpa ada paksaan dorongan orang lain, tetapi atas dasar kemauan sendiri. Motivasi Ekstrinsik adalah jenis motivasi yang timbul sebagai akibat pengaruh dari luar individu, apakah karena adanya ajakan, suruhan, atau paksaan dari orang lain sehingga dengan keadaan demikian siswa mau melakukan sesuatu atau belajar.

Bagi siswa yang selalu memperhatikan materi pelajaran yang diberikan, bukanlah masalah bagi guru. Karena di dalam diri siswa tersebut ada motivasi, yaitu motivasi intrinsik. Siswa yang demikian biasanya dengan kesadaran sendiri memperhatikan 
penjelasan guru. Rasa ingin tahunya lebih banyak terhadap materi pelajaran yang diberikan. Berbagai gangguan yang ada disekitarnya, kurang dapat mempengaruhinya agar memecahkan perhatiannya. Lain halnya bagi siswa yang tidak ada motivasi di dalam dirinya, maka motivasi ekstrinsik yang merupakan dorongan dari luar dirinya mutlak diperlukan.

Siswa yang belajar di sekolah dasar tidak hanya dinilai dari kemampuan akademiknya tetapi seharusnya siswa juga dinilai dari segala aspek kemampuan perkembangannya (Sakti, 2018a). Peran guru adalah membangkitkan motivasi siswa sekolah dasar sehingga siswa tersebut mau melakukan belajar dan memiliki peningkatan perkembangan.

Guru memotivasi siswa untuk berkeinginan belajar terus menerus dan memberi peluang untuk belajar sesuai dengan kemampuannya (Naim, 2009). Ada beberapa cara yang bisa digunakan oleh guru untuk menumbuhkan motivasi belajar siswa, sebagai berikut:

1. Menjelaskan tujuan belajar

Pada permulaan belajar mengajar seharusnya terlebih dahulu seorang guru menjelaskan mengenai Tujuan Instruksional Khusus yang akan dicapainya kepada siwa. Makin jelas tujuan maka makin besar pula motivasi dalam belajar.

2. Hadiah

Berikan hadiah untuk siswa yang berprestasi. Hal ini akan memacu semangat mereka untuk bisa belajar lebih giat lagi. Di samping itu, siswa yang belum berprestasi akan termotivasi untuk bisa mengejar siswa yang berprestasi.

3. Saingan atau kompetisi

Guru berusaha mengadakan persaingan di antara siswanya untuk meningkatkan prestasi belajarnya, berusaha memperbaiki hasil prestasi yang telah dicapai sebelumnya.

4. Pujian

Sudah sepantasnya siswa yang berprestasi untuk diberikan penghargaan atau pujian. Tentunya pujian yang bersifat membangun.

5. Hukuman

Hukuman diberikan kepada siswa yang berbuat kesalahan saat proses pembelajaran. Hukuman ini diberikan dengan harapan agar siswa tersebut mau merubah diri dan berusaha memacu motivasi belajarnya.

a. Membentuk kebiasaan belajar yang baik

b. Membantu kesulitan belajar anak didik secara individual maupun kelompok

c. Menggunakan metode yang bervariasi, dan

d. Menggunakan media yang baik dan sesuai dengan tujuan pembelajaran

Dengan melihat situasi dan kondisi saat proses pembelajaran berlangsung, seorang guru boleh memilih item yang cocok digunakan. Jika peserta didik berkurang bahkan hilang motivasinya dalam belajar, maka tujuan pendidikan sulit akan tercapai. Mahasiswa calon guru sekolah dasar harus dapat mengatasi hal tersebut. Hal inilah yang menyebabkan mahasiswa Program Studi Pendidikan Guru Sekolah Dasar harus menghasilkan karyakarya supaya dipahami anak sekolah dasar (Sakti, 2018b).

Program studi pendidikan guru sekolah dasar merupakan program studi (prodi) yang mengarahkan mahasiswa untuk memiliki keahlian di bidang sekolah dasar (Sakti, 2017b). Peran guru sekolah dasar di zaman sekarang memang dituntut untuk selalu siaga memacu siswa agar tidak ketinggalan selangkahpun. Guru sekarang harus dinobatkan sebagai 
orang yang bertangan dingin, berhati lapang, siap untuk mengabdi untuk anak-anak bangsa, di mana dan kapan pun.

\section{KESIMPULAN}

Orang tua dan guru perlu memberikan penanaman nilai-nilai moral dan nilai-nilai positif agar siswa tidak mudah terjerumus ke dalam hal-hal yang negatif dan dapat menyaring tontonan yang sebaiknya ia lihat. Peran orang tua dan guru memiliki kesamaan pengawasan dalam hal mendidik siswa sekolah dasar tetapi perbedaannya didapatkan pada tempatnya. Siswa sekolah dasar di didik dan diawasi oleh orang tua di rumah, sedangkan guru yang mengawasi siswa sekolah dasar di sekolah. Pengawasan guru dan orang tua sangat berperan untuk membentuk sikap dan pribadi anak menjadi lebih baik dan disiplin. Pendidikan anak dimulai dari pendidikan di rumah dan orang tua yang mempunyai tanggung jawab utama terhadap masa depan pendidikan anaknya. Apabila orangtua mampu menunjukkan kasih sayang kepada anak maka anak akan menjadi biasa dekat dengan orang tua. Peran guru adalah membangkitkan motivasi siswa sekolah dasar sehingga siswa tersebut mau melakukan belajar dan memiliki peningkatan perkembangan.

\section{REFERENSI}

Abidin, dkk. 2017. Pembelajaran Literasi. Jakarta: Bumi Aksara

Gih. 2019. Bahaya Laten Revolusi Industri 4.0 Itu Bernama Disrupsi SDM. Retrieved July 8, 2019, from https://www.cnnindonesia.com/ekonomi/20190220125959-92371114/ bahaya-laten-revolusi-industri-40-itu-bernama-disrupsi-sdm

Maharani. 2019. Panglima TNI: Hoaks Dampak Negatif Revolusi Industri 4.0 | Republika Online. Retrieved July 8, 2019, from https://nasional.republika.co.id/ berita/nasional/umum/ pp2tuf335/panglima-tni-emhoaks-emdampak-negatifrevolusi-industri-40

Naim, M. 2009. Menjadi Guru Inspiratif. Yogyakarta: Pustaka pelajar

Natarida. 2016. Pengaruh Tayangan Televisi Kepada Anak oleh Octavia Bella Natarida Halaman all - Kompasiana.com. Retrieved July 7, 2019, from https://www.kompasiana.com/octaviabella/570265a97797733e095813d3/pe ngaruh-tayangan-televisi-kepada-anak?page=all

Purwadi, D. 2019. Riset: 30 Juta Anak Indonesia Pengguna Internet | Republika Online. Retrieved July 7, 2019, from https://www.republika.co.id/berita/nasional/ umum/14/02/18/ n174jc-riset-30-juta-anak-indonesia-pengguna-internet

Sakti, B. P. 2016a. Etika Dan Profesi Guru SD Di Tengah Perkembangan Zaman. Proceeding PGSD Universitas Kuningan 2016, 1(1), 99-107. Retrieved from https://proceeding.uniku.ac.id/index.php/pgsd2016/article/view/10

Sakti, B. P. 2016b. Indikator Sekolah Dasar Ramah Anak. Prosiding Seminar Nasional PKO FKIP UTP, 163-176. Retrieved from http://ejournal.utp.ac.id/ index.php/PROPKO/article/view/ 596

Sakti, B. P. 2017a. Indikator Pengembangan Karakter Siswa Sekolah Dasar. Magistra Unwidha Klaten, 30, 1. Retrieved from http://journal.unwidha.ac.id/index.php/ MAGISTRA/ article/view/1/0

Sakti, B. P. 2017b. Persepsi Mahasiswa Program Studi Pendidikan Guru Sekolah Dasar Universitas Widya Dharma Tentang Etika Mahasiswa. Premiere Educandum : Jurnal Pendidikan Dasar Dan Pembelajaran, 7(02), 135. https://doi.org/10.25273/pe.v7i2.1732 
Sakti, B. P. 2018a. Feasibility Indicators Of Study Books Used Elementary School. SHEs: Conference Series 1, 1(Snpd), 103-111. Retrieved from https://jurnal.uns.ac.id/SHES/article/ view/23556

Sakti, B. P. 2018b. Training of Scientific Papers Writing On Students of Widya Dharma University. CARADDE: Jurnal Pengabdian Kepada Masyarakat, 1(1), 7-12. https://doi.org/10.31960/caradde.v1i1.3

Suherlan, D. 2018. Hati-hati, Perkembangan Teknologi Digital Bawa Dampak Negatif Terhadap Anak. Retrieved July 8, 2019, from https://jabarnews.com/read/ 40784/hati-hati-perkembangan-teknologi-digital-bawa-dampak-negatifterhadap-anak

Yudhoyono, S. B. 2008. Peraturan Pemerintah Republik Indonesia Nomor 74 Tahun 2008 Tentang Guru, 153-164.

Yul. 2019. 13 SD Berpotensi Bermasalah, Saat PPDB Tahun 2019 -batampos.co.id. Retrieved July 8, 2019, from https://batampos.co.id/2019/03/31/13-sdberpotensi-bermasalah-saat-ppdb-tahun-2019 